OPEN ACCESS

Edited by: Andrew Butterworth,

University of Bristol, UK

Reviewed by:

Ruth Davis,

University of Wollongong, Australia

Mark Peter Simmonds,

University of Bristol, UK

${ }^{*}$ Correspondence:

A. Mel Cosentino

orcinus.orca.1758@gmail.com

Specialty section

This article was submitted to Marine Affairs and Policy,

a section of the journal

Frontiers in Marine Science

Received: 18 April 2016

Accepted: 24 August 2016 Published: 16 September 2016

Citation:

Cosentino AM and Fisher S (2016) The Utilization of Aquatic Bushmeat from Small Cetaceans and Manatees

in South America and West Africa.

Front. Mar. Sci. 3:163

doi: 10.3389/fmars.2016.00163

\section{The Utilization of Aquatic Bushmeat from Small Cetaceans and Manatees in South America and West Africa}

\author{
A. Mel Cosentino ${ }^{1 *}$ and Sue Fisher $^{2}$ \\ ${ }^{1}$ Wild Earth Foundation, Puerto Pirámides, Argentina, ${ }^{2}$ Department of Marine Wildlife, Animal Welfare Institute, Washington, \\ $D C$, USA
}

Aquatic bushmeat can be defined as the products derived from wild aquatic megafauna (e.g., marine mammals) that are used for human consumption and non-food purposes, including traditional medicine. It is obtained through illegal or unregulated hunts as well as from stranded (dead or alive) and bycaught animals. In most South American and West African countries aquatic mammals are or have been taken for bushmeat, including 33 small cetaceans and all three manatee species. Of these, two cetacean species are listed in the IUCN red list as "near threatened," and one as "vulnerable," as are all manatee species. Additionally, 22 cetacean species are listed as "data deficient," hence some of these species may also be at risk. No reports (recent or otherwise) were found for some countries, caution is needed in concluding that aquatic bushmeat is not utilized in these nations. Moreover, although aquatic bushmeat is mostly obtained opportunistically and was likely originally taken only for local consumption, directed catches occur in most countries and may have reached unsustainable levels in some areas. For example, in Peru and Nigeria, thousands of small cetaceans are illegally hunted annually. Reliable, recent data and a better overall understanding of the drivers of aquatic bushmeat will be essential in the development of effective mitigation measures.

Keywords: small cetaceans, manatees, hunting, bycatch, food, bait

\section{INTRODUCTION}

Products derived from marine mammals, particularly cetaceans, that are used for food, bait or cash have been termed "marine bushmeat" by the scientific community (e.g., Alfaro and Van Waerebeek, 2001; Clapham and Van Waerebeek, 2007). Here, we adopt the term "aquatic bushmeat" as recently defined by the Convention on the Conservation of Migratory Species of Wild Animals (CMS) as the products sourced from wild aquatic megafauna (e.g., marine mammals, including riverine species) that are used for human consumption and other non-food purposes including traditional uses. Aquatic bushmeat is obtained through illegal or unregulated hunts as well as from stranded (dead or alive) and/or bycaught animals (CMS, 2016).

A thorough literature search of published and unpublished materials available online was conducted in English, Spanish, and French. The search included videos, news, and local organization websites. Additionally, the marine mammal community was approached via the mailing list MARMAM. Further information was also obtained by contacting individual authors and organizations. 
Our findings suggest that aquatic mammal utilization as bushmeat is still common in many countries in America and Africa, reaching unsustainable levels in some areas. Here we present a brief literature review of the utilization of aquatic bushmeat from small cetaceans (dolphins, porpoises and beaked whales) and manatees in South America and West Africa.

\section{WEST AFRICA}

There is no evidence of organized manatee exploitation in Benin although killing a manatee is an important event in a fisherman's life (Rihanath Olga and Tchibozo, 2008). Meat and body parts are used, inter alia, for food, therapeutic purposes and traditional ceremonies (Tchibozo, 2002; Dossou-Bodjrènou et al., 2004). Information on cetaceans in Benin is virtually nonexistent. Sohou et al. (2013) is one of the only dedicated articles in the literature. The authors recorded the existence of at least nine cetacean species, some of which are occasionally consumed (Sohou et al., 2013).

The use of small cetaceans for human consumption and handicraft production in Cape Verde dates back several decades (Reiner et al., 1996). Products obtained opportunistically (e.g., from mass strandings) are used for food, handicrafts and decorations (Reiner et al., 1996; Hazevoet et al., 2010; Van Waerebeek et al., Unpublished). Recent reports indicate that the use of stranded and bycaught dolphin carcasses still occurs, although there is no current evidence of directed hunt (Brito and Carvalho, 2013).

Manatees are widely and illegally hunted by fishermen in The Gambia for food and traditional medicine (Powell, 1996; Jallow, 2008). Exploitation of small cetaceans may occur on a minor scale, mainly for food (Murphy et al., 1997; Alfaro and Van Waerebeek, 2001) but also for medicinal uses (Leeney et al., 2015).

Although the general public in Ghana did not consider dolphin meat edible until the late 1980s, that is no longer the case (Van Waerebeek and Ofori-Danson, 1999; Alfaro and Van Waerebeek, 2001). In fact, captures of cetaceans in Ghana are currently among the highest in West Africa, both in terms of animals landed and the number of species caught (e.g., Robards and Reeves, 2011). Small cetaceans were originally obtained as bycatch, however, direct catches now occur, at least in Apam, Dixcove, and Axim, where landing rates have greatly increased since the mid-1990s. For example, landings in Apam increased from 1.117 per month in the period 1995-1999, to 5.57 between 2001 and 2003 (Ofori-Danson et al., 2003; Debrah et al., 2010). Further, between January 2013 and February 2014, a minimum of 743 small cetaceans were landed at Dixcove alone, which represents an increase of almost 400\% since 2003 (Debrah et al., 2010; Van Waerebeek et al., 2014). The entire animal, bones attached, is hacked into small, individual portions for sale, which explains the lack of bony remains on beaches (Van Waerebeek and Ofori-Danson, 1999). All body parts are used, including the internal organs, both for food and as bait (OforiDanson et al., 2003; Weir et al., 2008; Van Waerebeek et al., 2009, 2014; Debrah et al., 2010; Robards and Reeves, 2011;
Weir and Pierce, 2013). Manatees hold different values between communities, some of which hunt them for food (Powell, 1996; Amlalo, 2008) while others kill them for bait (Ofori-Danson et al., 2008).

Some cultures in Guinea hunt manatees; their meat is typically consumed within the hunter's family, or shared between fishermen and hunters from the village, and their oil and bones are used for medicinal purposes (Powell, 1996; Keita, 2002; Richard et al., 2008). There is little evidence of small cetaceans being used as bushmeat (Van Waerebeek et al., 2004; Bamy et al., 2010).

Manatee hunting is probably declining in Guinea-Bissau, although incidental captures are currently the main threat (Sa et al., 2008). Products are used for food and other purposes (Powell, 1990; Silva et al., 1998; Silva and Araújo, 2001). Bycaught dolphins are also consumed locally and used in traditional ceremonies and for medicinal purposes (Leeney et al., 2015).

Manatees were heavily hunted in Ivory Coast in the 1980s and illegal hunting by specialized hunters continues (Powell, 1996; Perrin, 2001; Kouadio, 2008). Some communities hunt manatees for food. For example, the Ahizi consider manatee hunters heroes, although they are allowed to only kill three manatees during their lives. There are no recent reports of small cetaceans being used as bushmeat (Maigret, 1994).

Manatees have been hunted in Liberia for many decades, and probably to this day, using harpoons and guns (Robinson, 1971; Wiles and Makor, 2008).

In Mali manatees were hunted using a variety of methods for food and medicinal purposes, although hunting is currently uncommon (Powell, 1996; Perrin, 2001; Kienta et al., 2008).

There is little evidence for small cetacean bushmeat in Mauritania (Van Waerebeek et al., 2004) and no reports were found of the use of manatees as bushmeat.

Manatees are illegally hunted in Niger, along the Niger River, including for traditional ceremonies during the annual Sorko celebration. Their meat and other body parts are sold in markets (Malam Issa, 2008; Abbagana, 2013).

Nigeria appears to be one the largest consumers of small cetacean bushmeat in West Africa, with recent annual catches (both accidental and intentional) estimated at 10,000 dolphins (Lewison and Moore, 2012). Dolphins are captured using nets and, even when found alive, are butchered for human consumption (Uwagbae and Van Waerebeek, 2010). Manatee hunting was intensive in the past (Henshaw and Child, 1972; Sikes, 1974; Maigret, 1994; Angelici et al., 2001) and continues today for consumption and medicinal purposes despite a decline in the manatee population (Adeola, 1992; Maigret, 1994; Perrin, 2001; Oboto, 2002; Fa et al., 2006; Awobamise, 2008).

In Senegal, Atlantic humpback dolphins (Sousa teuszii) have been consumed opportunistically since the 1990s (Maigret, 1994; Van Waerebeek et al., 2004, 2008). Dolphin meat continues to be illegally traded as food and bait in the cephalopod fishery (Van Waerebeek et al., 1997a; Leeney et al., 2015). Manatees were caught historically (Maigret, 1994; Van Waerebeek et al., 1997a), on a scale that brought the population almost to extinction (Perrin, 2001). When incidental captures occur today, the meat is consumed and the oil used for medicinal purposes (Maigret, 
1994; Powell, 1996; Van Waerebeek et al., 1997a; Diop, 2006; Ba et al., 2008).

Manatees have been hunted with nets and harpoons in Sierra Leone at least since the 1980s (Reeves et al., 1988), and exploitation likely continues (Siaffa and Jalloh, 2008). Additionally, rice farmers see manatees as pests and use traps to catch them (Reeves et al., 1988). Virtually the entire body is used (Maigret, 1994; Powell, 1996; Perrin, 2001; Siaffa and Jalloh, 2008). There is only little evidence of small cetacean bushmeat (Maigret, 1994).

In Togo, manatees are illegally hunted for their meat, which is sold and consumed locally and used in traditional medicine and ceremonies (Segniagbeto et al., 2008). Small cetaceans obtained from opportunistic and intentional captures are landed at Lomé harbor, where they are butchered and sent to other localities (Alfaro and Van Waerebeek, 2001; Segniagbeto et al., 2014).

\section{SOUTH AMERICA}

In Argentina, bycaught porpoise and dolphin species were used for human consumption in the past (Crespo et al., 1994; Goodall et al., 1994; Ott et al., 2002; Robards and Reeves, 2011).

In Bolivia, botos are accidentally caught in fishing nets; their meat isused as bait or consumed by indigenous groups, and their oil used as medicine (Aliaga-Rossel, 2002; Trujillo et al., 2010, 2013; Robards and Reeves, 2011). No reports of manatee bushmeat were found.

Small cetaceans obtained opportunistically off the Atlantic coast of Brazil are used for food, bait, medicine and handicrafts (Siciliano, 1994; Ott et al., 2002; Alves and Rosa, 2008; Tosi et al., 2009; Oliveira de Meirelles et al., 2010; Trujillo et al., 2010). In the Brazilian Amazon River basin botos (Inia spp.) are illegally hunted for their meat to use as bait for fishing the scavenger catfish (Calophysus macropterus) known as piracatinga in Brazil, mota in Colombia, simi in Peru and mapurite in Venezuela (Flores et al., 2008; Gómez et al., 2008; Trujillo et al., 2010; Pinto de Sá Alves et al., 2012). The effect of these hunts is unknown as there are no available abundance estimates for river dolphins in their distribution range (BoteroArias et al., 2014; Salinas et al., 2014). Evidence, however, suggests that some boto populations may be impacted; for example, da Silva et al. (2011) found a 10\% annual reduction of boto abundance in a well-studied population, since 2000. It is estimated that 1650 dolphins are caught annually near Tefé alone (in Central Amazon), but a large number of other towns and villages in the Amazon target piracatinga using dolphin products as bait (da Silva and Martin, 2007; da Silva et al., 2011).

The West Indian (Trichechus manatus) and the Amazonian manatees (Trichechus inunguis) are present in Brazil (UNEP, 2010). They were hunted historically for their skin for making leather products (Domning, 1982). Today manatees are harvested for food and other uses (Lima et al., 1992; UNEP, 2010; Gómez et al., 2012; Franzini et al., 2013). At least 32 manatee hunters were active in 2014 (de Souza et al., 2014).

Over 7600 dolphins were killed for bait in the centolla King crab (Lithodes santolla) fishery in southern Chile between
1976 and 1979. Laws were adopted to protect dolphins but enforcement was poor (Cárdenas et al., 1987; Aguayo et al., 1998; Altieri and Rojas, 1999). The decline of crab abundance, the use alternative baits and other factors greatly reduced illegal hunts in the 1990s (Lescrauwaet and Gibbons, 1994; Van Waerebeek et al., 1997b). Small cetaceans were also killed in central Chile (Van Waerebeek et al., 1999) in the 1970s for bait in the longline fishery (Aguayo et al., 1998) and, although recent reports are scarce, in 2014 local fishermen were arrested for fileting a dolphin. Dolphins caught intentionally in Northern Chile in the 1970s1980s were used for food and bait (see Aguayo et al., 1998).

In the Colombian Amazon, boto, and, rarely, tucuxi (Sotalia fluviatilis) dolphins have been hunted since the late 1980s at least (Beltrán and Trujillo, 1992). Body parts are used as aphrodisiacs and amulets, and their oil for medicinal uses (see Trujillo et al., 2010). However, the main use of botos is as bait to fish "mota" (Trujillo et al., 2011; Salinas et al., 2014). On the Pacific coast, hunts for dolphins for bait became common by 1990 (Vidal et al., 1994; Ávila et al., 2008). Mother-calf pairs were frequently targeted (Ávila et al., 2008). Evidence suggests directed hunts still occur (Flórez-González and Capella, 2010). West Indian manatees were heavily exploited in the 18th and 19th Centuries (Mancera Rodríguez and Reyes García, 2008), with bombs and nets used (Lima et al., 1992). Although directed hunts are uncommon, manatees are still targeted for food, for their leather to make whips, and for other purposes (Romero and Creswell, 2005; Arévalo-González et al., 2010; Cruz-Antía and Gómez, 2011; UNEP, 2010; Fundación Natütama, 2013; Kiszka, 2014).

In Ecuador, indigenous Amazonian tribes, such as the Siona, traditionally exploited Amazonian manatees for subsistence (Timm et al., 1986) and non-food uses. Recent reports suggest hunting still occurs (Denkinger, 2010; Brice, 2014). No reports of small cetacean bushmeat were found.

Native Americans in French Guiana historically hunted West Indian manatees for private consumption or for religious traditions (Spiegelberger, 2002), although the practice is now uncommon (Romero and Creswell, 2005; UNEP, 2010). Dolphins were occasionally harpooned for fish bait in the past (Vidal et al., 1994).

In Guyana there is probably no organized hunting of West Indian manatees, although they may be taken opportunistically (UNEP, 2010). No reports of small cetacean bushmeat were found.

The greatest exploitation of small cetaceans in South America occurs in Peru, where they have been intentionally and incidentally caught in fishing nets for several decades: an estimated 10,000 dolphins were landed annually in the 1980s (Read et al., 1988; Van Waerebeek and Reyes, 1990, 1994a). Harpooning was once opportunistic (Read et al., 1988), but became common toward the 1990s. Some fishermen also used dynamite to provoke dolphin "stampedes" into set gillnets (Van Waerebeek and Reyes, 1990). Dolphin meat was sold in local food markets, but most animals were shipped to Lima (Read et al., 1988).

Although hunting and trading of small cetaceans was banned in Peru in 1990, captures continued (Van Waerebeek et al., 1999, 2002; Majluf et al., 2002; Reyes et al., 2002; García-Godos, 
TABLE 1 | Small cetacean and manatee species that are or have been used as bushmeat in South America and West Africa.

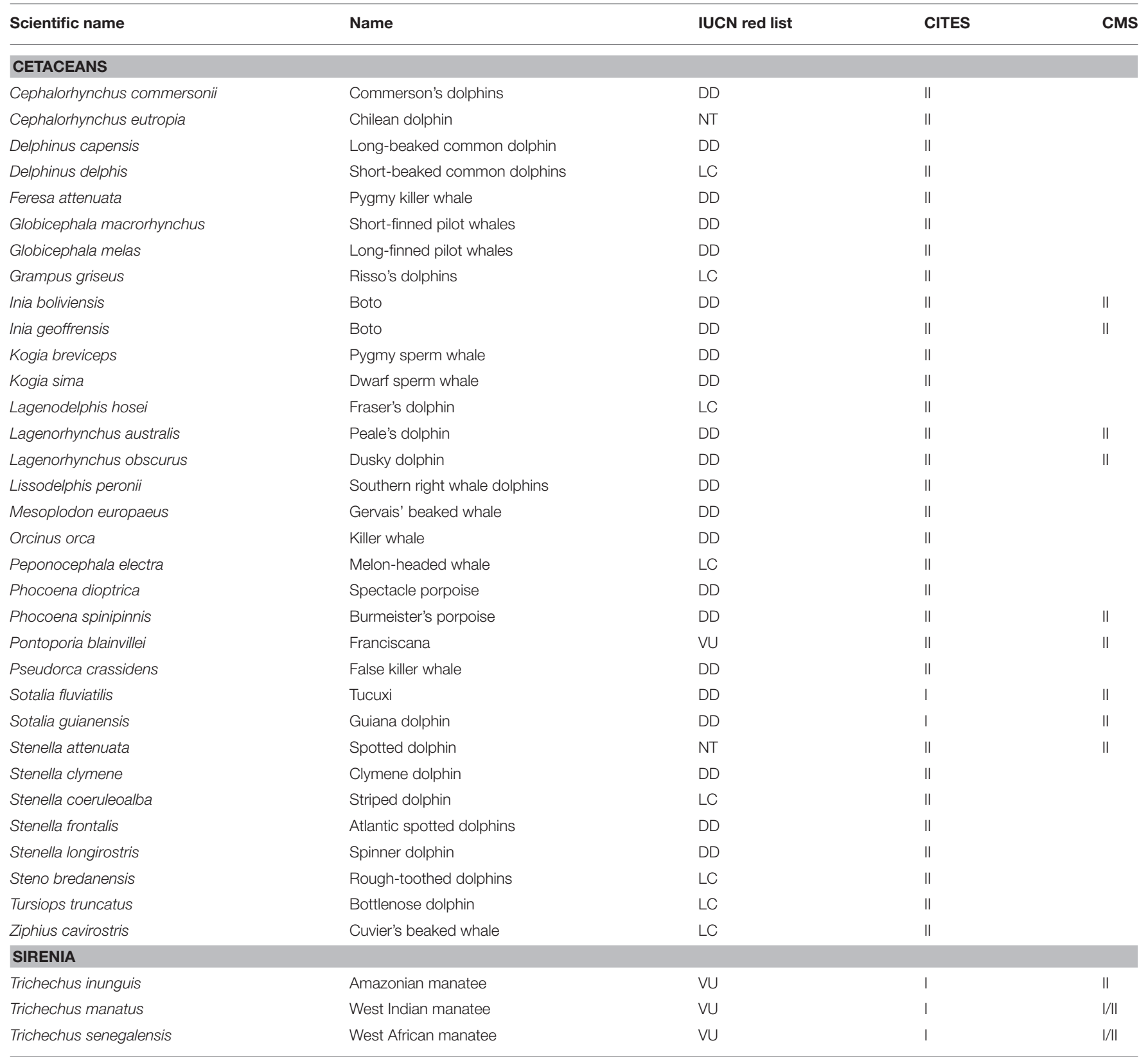

VU, Vulnerable; DD, Data Deficient; NT, Near Threatened; LC, Least Concern; IUCN, International Union for Conservation of Nature; CMS, Convention on Migratory Species; CITES, Convention on International Trade of Endangered Species.

2007; Mangel et al., 2010; Mangel, 2012) and by 1993 the annual estimated catch was 15,000-20,000 dolphins, exceeding the previous, legal, hunt (Van Waerebeek and Reyes, 1994b). In the late 1990s, dolphin products started to also be used as shark bait (Van Waerebeek et al., 1999). The annual catch estimate increased in the 2000s as products from harpooned and bycaught dolphins were also sold in local food markets and consumed onboard fishing vessels or at home. The use as bait has rapidly expanded and incidental and directed catches still occur (Tzika et al., 2010), as well as butchering of live stranded animals (García-Godos and Cardich, 2010).
Amazonian manatees are hunted in Peru to this day despite legal protection. Currently, however, they are mainly bycaught. Their meat is consumed (Reeves et al., 1996; Hidalgo Taricuarima, 2010) and skin, fat, and bones are occasionally used for medicinal purposes (Reeves et al., 1996; Elcacho Rovira, 2013; Silva et al., 2014). They are also captured alive to be "grown" for consumption, kept as pets, or even to be displayed in restaurants (Perea-Sicchar et al., 2011).

In Venezuela, the use of dolphins for bait and food has increased significantly since the 1970s (Vidal et al., 1994), with the Government even considering their commercial exploitation 
for food in the 1990s (Romero et al., 1997). Current removals (intentional and incidental) are estimated at 1000 animals annually (Robards and Reeves, 2011). Body parts are also used by some indigenous communities for religious events and medicinal purposes (Romero et al., 1997; Trujillo et al., 2010). West Indian manatees have been exploited for food, fuel, medicine, leather and cooking oil (PNUMA, 1995), since pre-Columbian times (Mondolfi, 1974; Romero and Creswell, 2005; UNEP, 2010) and manatee meat was found in markets until relatively recently (O'Shea et al., 1988). Some animals are also live captured for public display (UNEP, 2010).

\section{CONCLUSIONS}

In most South American and West African countries aquatic mammals are or have been used as bushmeat, encompassing at least 33 small cetaceans and all manatee species. Although in most cases the practice likely began opportunistically for local consumption, in some countries it has evolved to include directed catches and may have expanded to unsustainable levels.

Of the 33 small cetacean species recorded in this study, two are listed in the International Union for Conservation of Nature (IUCN) red list as "near threatened" and two as "vulnerable," as are all manatee species. Additionally, 22 cetacean species are listed as "data deficient," therefore some may also be at risk. Moreover, many populations are considered threatened, while the species is not. All these species are listed on the Convention on International Trade in Endangered Species of Wild Fauna and Flora (CITES) appendices signifying that their status could be compromised by trade of their products. However, as CITES regulates only international trade and aquatic bushmeat trade is typically domestic, the treaty offers little protection. Additionally, some species are included in the appendices of the Convention

\section{REFERENCES}

Abbagana, A. L. (2013). Situation du lamantin au Niger. Report to the Ministere de L'environnement, de la Salubrite Urbaine et du Developpement Durable, Direction de L'environnement et des Eaux et Forets, Direction de la Faune, de la Chasse et des Aires Protegees, Republique du Niger, 7.

Adeola, M. O. (1992). Importance of wild animals and their parts in the culture, religious festivals, and traditional medicine, of Nigeria. Environ. Conserv. 19, 125-134. doi: 10.1017/S0376892900030605

Aguayo, A., Navarro, D. T., and Ram, J. A. (1998). Los mamíferos marinos de Chile: 1. Cetacea. Ser. Client. INACH 48, 19-159.

Alfaro, J., and Van Waerebeek, K. (2001). "Drowning in a sea of silence: the bushmeat concept as applied to marine wildlife," in Zoos and Aquariums: Committing to Conservation (ZACC) (Orlando: ZACC), 16.

Aliaga-Rossel, E. (2002). Distribution and abundance of the river dolphin (Inia geoffrensis) in the Tijamuchi River, Beni, Bolivia. Aq. Mamm. 28, 312-323.

Altieri, M., and Rojas, A. (1999). La tragedia ecológica del "milagro" neoliberal chileno. Pers. Soc. XIII 1, 127-141.

Alves, R. R. N., and Rosa, I. L. (2008). Use of tucuxi dolphin Sotalia fluvialilis for medicinal and magic/religious purposes in North of Brazil. Hum. Ecol. 36, 443-447. doi: 10.1007/s10745-008-9174-5

Amlalo, M. (2008). "Ghana," in Conservation Strategy for the West African Manatee, eds T. Dodman, M. D. D. Ndiaye, and K. Sarr (Nairobi, Kenya and Wetlands International Africa; Dakar, Senegal: UNEP), 59-62. on the Conservation of Migratory Species of Wild Animals (CMS; Table 1) and most countries have domestic regulations that provide partial or full protection.

No recent information was found of the use of aquatic mammals for bushmeat in Uruguay, the Island of Saint Helena and São Tomé and Principe, after Robards and Reeves (2011). No reports were found for Suriname and Burkina Faso. The absence of information on aquatic bushmeat (recent or otherwise) is probably due to a lack of research and reporting rather than the non-existence of such use. A precautionary approach is recommended, and the absence of evidence should not be interpreted as evidence of absence. Moreover, despite legal protection, the use of small cetaceans and manatees for aquatic bushmeat appears to be growing.

Marine mammals are especially susceptible to exploitation due to low reproductive rates and the many other threats they face, including noise pollution and climate change (Perrin et al., 2009). An increase in knowledge and better understanding of the aquatic bushmeat issue is needed in order to implement local and international management programs for the effective monitoring and mitigation of unsustainable and illegal hunting and use of aquatic mammals. The work of the IWC Scientific Committee's Marine Bushmeat Intersessional Working Group, including holding dedicated regional workshops and formal liaison with other international bodies, such as CMS and the Convention on Biological Diversity (International Whaling Commission, 2016), is expected to provide a helpful contribution.

\section{AUTHOR CONTRIBUTIONS}

AC was responsible for researching related literature and preparing a first draft. SF was responsible for the general idea and from the first draft on, she contributed to editing.

Angelici, F. M., Egbide, B., and Akani, G. C. (2001). Some new mammal records from the rainforest of South-Eastern Nigeria. Hystrix 12, 37-43. doi: 10.4404/hystrix-12.1-4169

Arévalo-González, G. K., Castelblanco-Martínez, N., Sánchez-Palomino, P., and López-Arévalo, H. (2010). Uso de metodologías complementarias para la determinación del tamaño de la población de manatí (Trichetus manatus) en la Ciénaga de Pareces (Santander, Colombia). Mem. Conf. Interna Med. Aprovech. Fauna Silv. Exot. Conv. 6, 2.

Ávila, I. C., García, C., and Bastidas, J. C. (2008). A note on the use of dolphins as bait in the artisanal fisheries off Bahía Solano, Chocó, Colombia. J. Cetacean Res. Manage. 10, 179-182.

Awobamise, A. (2008). "Nigeria," in Conservation Strategy for the West African Manatee, eds T. Dodman, M. D. D. Ndiaye, and K. Sarr (Nairobi, Kenya and Wetlands International Africa; Dakar, Senegal: UNEP), 75-78.

Ba, E., Diop, M. D., Sarr, K., Mactar Niane, A., and Jaulin, M. (2008). “Senegal,” in Conservation Strategy for the West African Manatee, eds T. Dodman, M. D. D. Ndiaye, and K. Sarr (Nairobi, Kenya and Wetlands International Africa; Dakar, Senegal: UNEP), 26-30.

Bamy, I. L., Van Waerebeek, K., Bah, S. S., Dia, M., Kaba, B., Keita, N., et al. (2010). Species occurrence of cetaceans in Guinea, including humpback whales with Southern Hemisphere seasonality. Mar. Biod. Rec. 3:e48. doi: 10.1017/S1755267210000436

Beltrán, S., and Trujillo, F. (1992). Mortalidad Incidental y dirigida de Inia Geoffrensis y Sotalia fluviatilis, en la Amazonia y Orinoquie colombiana. 
Abstract retrieved from Resúmenes, 5ta Reunión de Especialistas en Mamíferos Acuáticos de América del Sur, Buenos Aires.

Botero-Arias, R., de Lima Franco, D., and Marmontel, M. (2014). Caiman and Dolphin Mortality Associated to the Piracatinga Fishery in the Mid Solimões River Region - Amazonas, Brazil. Report to the Ministry of Science, Technology and Innovation, Tefé, 60

Brice, C. E. (2014). The Detection of Amazonian Manatees (Trichechus inunguis) Using Side-Scan Sonar and the Effect of Oil Activities on their Habitats in Eastern Ecuador. Master's thesis. Nova Southeastern University. Retrieved from NSUWorks, Oceanographic Center. Available online at: http://nsuworks.nova.edu/occ_stuetd/8

Brito, C., and Carvalho, I. (2013). "Blackfish off Cape Verde Islands: the need for future effort to assess distribution, abundance and interactions with human activities," in Atas do colóquio Internacional Cabo Verde e Guiné-Bissau: Percursos do Saber e da Ciência. Lisboa: Instituto de Investigação Científica Tropical.

Cárdenas, J. C., Gibbons, J., Oporto, J., and Stutzin, M. (1987). Impacto de la pesquería de centolla y centollón sobre las poblaciones de mamíferos marinos de Magallanes, Chile. Amb. y Des. 3, 111-119.

CMS (2016). Aquatic Bushmeat. UNEP/CMS/ScC-SC1/Doc.10.2.2. CMS.

Clapham, P., and Van Waerebeek, K. (2007). Bushmeat and bycatch: the sum of the parts. Mol. Ecol. 16, 2607-2609. doi: 10.1111/j.1365-294X.2007.03378.x

Crespo, E. A., Corcuera, J. F., and López Casorla, A. (1994). Interactions between marine mammals and fisheries in some coastal fishing areas of Argentina. Rep. Int. Whal. Commn. 15, 269-281.

Cruz-Antía, D., and Gómez, J. R. (2011). Aproximación al uso y tráfico de fauna silvestre en Puerto Carreño, Vichada, Colombia. Amb. y Des. 14, 63-94. Available online at: http://revistas.javeriana.edu.co/index.php/ ambienteydesarrollo/article/view/1094

da Silva, V. M. F., and Martin, A. R. (2007). "Impact of human activities upon two species of dolphins in Amazonian flooded forest, Brazil," in Abstract of the 17th Biennial Conference on the Biology of Marine Mammals (Cape Town: Society for Marine Mammalogy).

da Silva, V. M. F., Martin, A. R., and Do Carmo, N. A. S. (2011). Amazonian fisheries pose threat to elusive dolphin species. Species $53,10-11$.

Debrah, J. S., Ofori-danson, P. K., and Van Waerebeek, K. (2010). An Update on the Catch Composition and Other Aspects of Cetacean Exploitation in Ghana. IWC SC/62/SM10.

Denkinger, J. (2010). Status of the Amazonian manatee (Trichechus inunguis) in the Cuyabeno Reserve, Ecuador. Avances 2, b29-b34.

de Souza, D. A., Ferreira da Silva, V. M., Fernandes da Silva, J. C., von Muhlen, E. M., Pinassi Antunes, A., and Rossoni Cardoso, F. (2014). Conservation prospects for the Amazonian manatee in the lower Purus River, Central Amazon, Brazil. Sirenews 62, 6-8.

Diop, M. D. (2006). Conservation du Lamantin Ouest Africain Trichechus Senegalensis le Long du Littoral Ouest Africain: Enquête de Base Dans la Réserve de Biosphère du delta du Saloum (Sénégal) September 2005. Wetlands International Report. Survey team of IUCN and Parc Nationale Delta du Saloum.

Domning, D. P. (1982). Commercial exploitation of manatees Trichechus in Brazil c. 1785-1973. Biol. Conserv. 22, 101-126.

Dossou-Bodjrènou, S. J., Sagbo, P., and Boko, J.-M. (2004). Education, Conservation et Recherches sur le Lamantin d'Afrique Dans les Zones Humides $d u$ Sud-Benin. Rapport d'Activité N ${ }^{\circ}$ 002-PL-NT, Nature Tropicale, ONG, 28.

Elcacho Rovira, M. (2013). Percepción Social Sobre el Manatí Amazónico, Trichechus Inunguis, en Iquitos (Perú). MSc. thesis, Barcelona: Instituto de Ciencia y Tecnología Ambiental (ICTA), Universidad Autónoma de Barcelona.

Fa, J. E., Seymour, S., Dupain, J., Amin, R., Albrechtsen, L., and Macdonald, D. (2006). Getting to grips with the magnitude of exploitation: Bushmeat in the Cross-Sanaga rivers region, Nigeria and Cameroon. Biol. Conserv. 129, 497-510. doi: 10.1016/j.biocon.2005.11.031

Flores, P. A. C., Trujillo, F., Rocha-Campos, C. C., Marini-Filho, O. J., Da Silva, V. M. F., Martin, A. R., et al. (2008). The Status of "Piracatinga" Fishery using AMAZON Botos As Bait in South America. IWC SC/60/SM17.

Flórez-González, L., and Capella, J. (2010). "Interacción pesquería-cetáceos: captura incidental en el Pacífico Sur de Colombia," in Esfuerzos Para Mitigar el Impacto De Actividades Pesqueras en Cetáceos en Los Países del Pacífico Sudeste, ed F. Félix (Guayaquil: CPPS), 14-20.
Franzini, A. M., Castelblanco-Martínez, D. N., Rosas, F. C. W., and da Silva, V. M. F. (2013). What do local people know about Amazonian manatees? Traditional ecological knowledge of Trichechus inunguis in the oil Province of Urucu, AM Brazil. Nat. Conserv. 11, 75-80. doi: 10.4322/natcon.2013.012

Fundación Natütama (2013). Caminos Para la Conservación: Monitoreo y Manejo de la Fauna Acuática Con la Comunidad. Colombia. Unpublished Report, 67.

García-Godos, I. (2007). "Revisión de las interacciones entre cetáceos y la pesquería marina peruana: perspectivas para la conservación de cetáceos en Perú," in Memorias del Taller de Trabajo Sobre el Impacto de las Actividades Antropogénicas en Mamíferos Marinos en el Pacífico Sudeste, ed F. F. Bogotá, (Colombia: CPPS/PNUMGuayaquil Ecuador, A), 77-82.

García-Godos, I., and Cardich, C. (2010). First mass stranding of Risso's dolphins (Grampus griseus) in Peru and its destiny as food and bait. Mar. Biod. Rec. 3, e3. doi: 10.1017/S1755267209991084

Gómez, A., Rodríguez, J., Jiménez, N., Cabezas, F., Rodríguez, J. E., and Matamoros, Y. (eds.). (2012). "Viabilidad de la población y el hábitat del manatí (Trichechus Manatus Manatus) en el Caribe," in Estrategia para la conservación de la especie. Zoológico y Jardín Botánico Nacional Simón Bolívar. UICN/SSC Conservation Breeding Specialist Group-Mesoamérica (San José: CBSG Mesoamérica).

Gómez, C., Trujillo, F., Diazgranados, M. C., and Alonso, J. (2008). “Capturas dirigidas de delfines de río en la Amazonia para la pesca de mota (Calophysus macropterus): una problemática regional de gran impacto," in Fauna Acuática Amenazada en la Amazonia Colombiana. Análisis y Propuestas Para su Conservación, eds F. Trujillo, J. C. Alonso, M. C. Diazgranados, and C. Gómez (Bogotá: Fundación Omacha, Fundación Natura, Instituto Sinchi y Corpoamazonia), 39-57.

Goodall, R. N. P., Schiavini, A. C. M., and Fermani, C. (1994). Net fisheries and net mortality of small cetaceans off Tierra del Fuego, Argentina. Rep. Int. Whal. Commn, 15, 295-306.

Hazevoet, C. J., Monteiro, V., López, P., Varo, N., Torda, G., Berrow, S., et al. (2010). Recent data on whales and dolphins (Mammalia: Cetacea) from the Cape Verde Islands, including records of four taxa new to the archipelago. Zoologia Caboverdiana 1, 75-99.

Henshaw, J., and Child, G. S. (1972). New attitudes in Nigeria. Oryx 11, 275-283.

Hidalgo Taricuarima, J. J. (2010). Evaluación preliminar del "manati” Amazónico Trichechus inunguis (Natterer, 1883) en el Río Lagartococha - Zona Reservada Güeppí, Loreto - Perú. Report to Ministerio del Ambiente, 24.

International Whaling Commission (2016). Report of the Scientific Committee. IWC/66/Rep01, 136. Available online at: https://archive.iwc.int/pages/view. php?ref=6127\&k

Jallow, A. (2008). "The Gambia," in Conservation Strategy for the West African Manatee, eds T. Dodman, M. D. D. Ndiaye, and K. Sarr (Nairobi, Kenya and Wetlands International Africa, Dakar: UNEP), 31-34.

Keita, N. (2002). Inventaire du Lamantin d'Afrique (Trichechus senegalensis) en République de Guinée. Unpublished Report, 10.

Kienta, M., Kone, B., and Timbo, S. (2008). "Mali," in Conservation Strategy for the West African Manatee, eds T. Dodman, M. D. D. Ndiaye, and K. Sarr (Nairobi, Kenya and Wetlands International Africa, Dakar: UNEP), 79-82.

Kiszka, J. (2014). Bycatch Assessment of the West Indian Manatee (Trichechus Manatus) and Other Megafauna In Artisanal Fisheries of the Caribbean. Report to SPAW-RAC, 41. Available online at: http://www.car-spaw-rac.org/?lang=en

Kouadio, A. (2008). "Côte D'ivoire/Ivory Coast," in Conservation Strategy for the West African Manatee, eds T. Dodman, M. D. D. Ndiaye, and K. Sarr (Nairobi, Kenya and Wetlands International Africa, Dakar: UNEP), 53-58.

Leeney, R. H., Dia, I. M., and Dia, M. (2015). Food, pharmacy, friend? Bycatch, direct take and consumption of dolphins in West Africa. Hum. Ecol. 43, 105-118. doi: 10.1007/s10745-015-9727-3

Lescrauwaet, A. C., and Gibbons, J. (1994). Mortality of small cetaceans and the crab bait fishery in the Magallanes Area of Chile since 1980. Rep. Int. Whal. Commn. 15, 485-494.

Lewison, R., and Moore, J. (2012). Improving Interview-Based Assessments of Sea Turtle and Marine Mammal Bycatch in West Africa: Putting Fishing Activity into A Socio-Economic Context. Project Report, San Diego State University and Southwest Fisheries Science Center, NOAA, 81.

Lima, R. P., Paludo, D., Soavinski, R. J., Silva, K. G., and Oliveira, E. M. A. (1992). Levantamento da distribuição, ocorrência e status de conservação do peixe-boi 
marinho (Trichechus manatus, Linnaeus, 1758) no litoral nordeste do Brasil. Peixeboi 1, 47-72.

Maigret, J. (1994). Marine mammals and fisheries along the West African coast. Rep. Int. Whal. Commn. 15, 307-316.

Majluf, P., Babcock, E. A., Riveros, J. C., Schreiber, M. A., and Alderete, W. (2002). Catch and bycatch of sea birds and marine mammals in the smallscale fishery of Punta San Juan, Peru. Conserv. Biol. 16, 1333-1343. doi: 10.1046/j.1523-1739.2002.00564.x

Malam Issa, A. (2008). "Niger," in Conservation Strategy for the West African Manatee, eds T. Dodman, M. D. D. Ndiaye, and K. Sarr (Nairobi, Kenya and Wetlands International Africa, Dakar: UNEP), $83-86$.

Mancera Rodríguez, N. J., and Reyes García, O. (2008). Comercio de fauna silvestre en Colombia/Wildlife trade in Colombia. Rev. Fac. Nal. Agr. Medellín 61, 4618-4645. Available online at: http://www.scielo.org.co/scielo.php?script=sci_ arttext\&pid=S0304-28472008000200015

Mangel, J. C., Alfaro-Shigueto, J., Van Waerebeek, K., Cáceres, C., Bearhop, S., Witt, M. J., et al. (2010). Small cetacean captures in Peruvian artisanal fisheries: high despite protective legislation. Biol. Conserv. 143, 136-143. doi: 10.1016/j.biocon.2009.09.017

Mangel, J. C. (2012). Interactions of Peruvian Small Scale Fisheries with Threatened Marine Vertebrate Species. PhD. thesis. Exeter, UK: University of Exeter.

Mondolfi, E. (1974). Taxonomy, distribution and status of the manatee in Venezuela. Memorias de la Sociedad de Ciencias Naturales La Salle. $34,5-23$.

Murphy, P. F., Van Waerebeek, K., and Jallow, A. O. (1997). Cetacean in Gambian Waters. IWC SC/49/SM11.

Oboto, E. (2002). Manatee status in River Benue and River Niger (Nigeria). Unpublished Report, 89.

Ofori-Danson, P. K., Self-Sullivan, C., Mombu, V. M., and Yelibora, M. A. (2008). Enhancing Conservation of the West African Manatee in Ghana (20pp). Annual Report 2007. Nature Conservation Research Centre, Accra, 45.

Ofori-Danson, P. K., Van Waerebeek, K., and Debrah, S. (2003). A survey for the conservation of dolphins in Ghanaian coastal waters. J. Ghana Sci. Assoc. 5, 45-54.

Oliveira de Meirelles, A. C., Ribeiro, A. C., Silva, C. P. N., and Soares Filho, A. A. (2010). Records of Guiana dolphin, Sotalia guianensis, in the State of Ceará, northeastern Brazil. Lat. Am. J. Aquat. Mamm. 8, 97-102. doi: 10.5597/lajam00157

O'Shea, T. J., Correa-Viana, M., Ludlow, M. E., and Robinson, J. G. (1988). Distribution, status, and traditional significance of the West Indian manatee Trichechus manatus in Venezuela. Biol. Conserv. 46, 281-301. doi: 10.1016/0006-3207(88)90030-4

Ott, P. H., Secchi, E. R., Moreno, I. B., Danilewicz, D., Crespo, E. A., Bordino, P., et al. (2002). Report of the working group on fishery interactions. Lat. Am. J. Aquat. Mamm. 1, 55-64. doi: 10.5597/lajam00008

Perea-Sicchar, C. M., Velásquez-Varela, L. J., Sánchez-Babilonia, J., EspinozaAzan, M., Lee-Richardson, D., and Sigler, L. (2011). Manejo y rehabilitación del manatí Amazónico (Trichechus inunguis) en cautiverio en el Perú. Ciencia Amazónica (Iquitos) 1, 104-113.

Perrin, W. F. (2001). Conservation status of the West African Manatee. Sirenews $36,34-40$.

Perrin, W. F., Würsig, B., and Thewissen, J. G. M. (2009). Encyclopedia of Marine Mammals, 2nd Edn., San Diego, CA: Elsevier.

Pinto de Sá Alves, L. C., Antunes Zappes, C., and Andriolo, A. (2012). Conflicts between river dolphins (Cetacea: Odontoceti) and fisheries in the Central Amazon: a path toward tragedy? Zoologia (Curitiba) 29, 420-429. doi: 10.1590/S1984-46702012000500005

Powell, J. A. (1990). Manatees in the Bijagos Archipelago: Recommendations for Their Conservation. Cameroon: IUCN Wetland Programme, 30.

Powell, J. A. (1996). The Distribution and Biology of the West African Manatee (Trichechus senegalensis Link, 1795). Nairobi, Kenya: United Nations Environment Programme, Regional Seas Programme, Oceans and Coastal Areas.

PNUMA (1995). Plan de Manejo Regional para el Manatí Antillano, Trichechus manatus. Technical Report to PAC No. 35. Programa Ambiental del Caribe del PNUMA, Kingston.
Read, A. J., Van Waerebeek, K., Reyes, J. C., McKinnon, J. S., and Lehman, L. C. (1988). The exploitation of small cetaceans in Coastal Peru. Biol. Conserv. 46, 53-70. doi: 10.1016/0006-3207(88)90108-5

Reeves, R. R., Leatherwood, S., Jefferson, T. A., Curry, B. E., and Henningsen, T. (1996). Amazonian manatees, Trichechus inunguis, in Peru: distribution, exploitation, and conservation status. Interciencia 21, 246-254.

Reeves, R. R., Tuboku-metzger, D., and Kapindi, R. A. (1988). Distribution and exploitation of manatees in Sierra Leone. Oryx 22, 75-84. doi: 10.1017/S0030605300027538

Reiner, F., dos Santos, M. E., and Wenzel, F. W. (1996). cetaceans of the Cape Verde archipelago. Mar. Mamm. Sci. 12, 434-443. doi: 10.1111/j.17487692.1996.tb00595.x

Reyes, J. C., Echegaray, M., and De Paz, N. (2002). “Distribución, comportamiento y conservación de cetáceos en el área Pisco-Paracas," in Memorias I Jornada Científica. Bases Ecológicas y Socioeconómicas para el Manejo de los Recursos Vivos de la Reserva Nacional de Paracas. eds J. Mendo and M. Wolf (Lima: Universidad Nacional Agraria La Molina), 136-144.

Richard, T., Ibrahima, C., Cécé Noel, K., Abdoulaye, D., Alhousséiny, D., and Cheick Ahmed Kassory, B. (2008). "Guinea," in Conservation Strategy for the West African Manatee, eds T. Dodman, M. D. D. Ndiaye, and K. Sarr (Nairobi, Kenya and Wetlands International Africa, Dakar: UNEP), 41-46.

Rihanath Olga, I., and Tchibozo, S. (2008). "Benin," in Conservation strategy for the West African manatee, eds T. Dodman, M. D. D. Ndiaye, and K. Sarr (Nairobi, Kenya and Wetlands International Africa, Dakar: UNEP), 71-74.

Robards, M. D., and Reeves, R. R. (2011). The global extent and character of marine mammal consumption by humans: 1970-2009. Biol. Conserv. 144, 2770-2786. doi: 10.1016/j.biocon.2011.07.034

Robinson, P. T. (1971). Wildlife trends in Liberia and Sierra Leone. Oryx 11, 117-122. doi: 10.1017/S0030605300009704

Romero, A., Agudo, A. I., and Green, S. M. (1997). Exploitation of Cetaceans in Venezuela. IWC SC/48/SM40.

Romero, A., and Creswell, J. (2005). "In the land of the mermaid: how culture, not ecology, influenced marine mammal exploitation in the South-eastern Caribbean," in Environmental issues in Latin America and the Caribbean, eds A. Romero, A., and S. E. West (New York, NY: Springer), 3-30.

Sa, J., Biai, J., da Cunha, L. R., da Silva Nagha, H., Djejo, F., Soares, J., et al. (2008). "Guinea-Bissau," in Conservation Strategy for the West African Manatee, eds T. Dodman, M. D. D. Ndiaye, and K. Sarr (Nairobi, Kenya and Wetlands International Africa, Dakar: UNEP), 35-40.

Salinas, C., Cubillos, J. C., Gómez, R., Trujillo, F., and Caballero, S. (2014). "Pig in a poke (gato por liebre)": The "mota" (Calophysus macropterus) fishery, molecular evidence of commercialization in Colombia and toxicological analyses. Ecohealth 11, 197-206. doi: 10.1007/s10393-013-0893-8

Segniagbeto, G. H., Akpamou, K. G., Tengue, K. T., Alassani, D., and Okoumassou, K. (2008). "Togo," in Conservation Strategy for the West African Manatee, eds T. Dodman, M. D. D. Ndiaye, and K. Sarr (Nairobi, Kenya and Wetlands International Africa, Dakar: UNEP), 63-70.

Segniagbeto, G. H., Van Waerebeek, K., Bowessidjaou, J. E., Ketoh, K., Kpatcha, T. K., Okoumassou, K., et al. (2014). Annotated checklist and fisheries interactions of cetaceans in Togo, with evidence of Antarctic minke whale in the Gulf of Guinea. Integr. Zool. 9, 1-13. doi: 10.1111/1749-4877.12011

Siaffa, D. D., and Jalloh, A. (2008). "Sierra Leone," in Conservation Strategy for the West African Manatee, eds T. Dodman, M. D. D. Ndiaye, and K. Sarr (Nairobi, Kenya and Wetlands International Africa, Dakar: UNEP), 47-50.

Siciliano, S. (1994). Review of small cetacean and fishery interactions in coastal waters of Brazil. Rep. Int. Whal. Commn. 15, 241-250.

Sikes, S. (1974). How to save the mermaids. Oryx 12, 465-470. doi: $10.1017 / \mathrm{S} 0030605300012266$

Silva, J., Montes, D., and Elías, R. (2014). Conocimientos, conservación y avistamiento del manatí Amazónico (Trichechus inunguis), según los pobladores de la cuenca del Río Ucayali (Loreto, Perú). Salud Tecnol. Vet. 2, 32-38. doi: 10.20453/stv.v2i1.2199

Silva, M. A., and Araújo, A. (2001). Distribution and current status of the West African manatee (Trichechus senegalensis) in Guinea-Bissau. Mar. Mamm. Sci. 17, 418-424. doi: 10.1111/j.1748-7692.2001.tb01285.x

Silva, M. A., Araújo, A., Djedjó, F., Gomes, L., and Monteiro, H. (1998). Plano Nacional de Conservação do manatim Africano (Trichechus senegalensis) 
na Guiné-Bissau: Resultado do inquérito Nacional e recomendações para a conservação da população. IUCN/ICN, 81.

Sohou, Z., Dossou-Bodjrenou, J., Tchibozo, S., Chabi-Yaoure, F., Sinsin, B., and Van Waerebeek, K. (2013). Biodiversity and status of cetaceans in Benin, West Africa: an initial assessment. West Afr. J. Appl. Ecol. 21, 121-134. Available online at: http://www.ajol.info/index.php/wajae/article/view/94736

Spiegelberger, T. (2002). Analysis of a habitat used by Antillean manatee (Trichechus manatus manatus) in French Guiana. Lehrstuhl für Vegetationsökologie. Technische Universität München.

Tchibozo, S. (2002). Etude pour la prospection des dernieres populations de lamantins (Trichechus senegalensis) dans la basse Vallee de l'oueme. Rep. Benin Minister Environ. 13.

Timm, R. M., Albuja, V. L., and Clauson, B. L. (1986). Ecology, distribution, Harvest, and conservation of the Amazonian Manatee Trichechus inunguis in Ecuador. Biotropica 18, 150-156. doi: 10.2307/2388757

Tosi, C. H., Magalhães, F. A., and Garri, R. G. (2009). Meat consumption of a Fraser's dolphin (Lagenodelphis hosei) stranded alive on the northern Brazilian coast. Mar. Biod. Rec. 2:e4. doi: 10.1017/S1755267208000043

Trujillo, F., Crespo, E., Van Damme, P. A., and Usma, J. S. (2010). The Action Plan for South American River Dolphins 2010-2020. WWF, Fundación Omacha, WDS, WDCS, Solamac, 249.

Trujillo, F., Diazgranados, M. C., Utreras, V., Aliaga-Rossel, E., and RodríguezMaldonado, M. V. (2011). Delfines de río en Suramérica. Fundación Omacha, Serie de Especies Amenazadas (Bogotá: Fundación Omacha), 64.

Trujillo, F., Gärtner, A., Caicedo, D., and Diazgranados, M. C., (eds.). (2013). Diagnóstico del estado de conocimiento y conservación de los mamíferos acuáticos en Colombia. Ministerio de Ambiente y Desarrollo Sostenible, Fundación Omacha, Conservación Internacional and WWF, 312.

Tzika, A. C., D’Amico, E., Alfaro-Shigueto, J., Mangel, J. C., Waerebeek, K., and Milinkovitch, M. C. (2010). Molecular identification of small cetacean samples from Peruvian fish markets. Conserv. Gen. 11, 2207-2218. doi: 10.1007/s10592-010-0106-8

UNEP (2010). Regional Management Plan for The West Indian Manatee (Trichechus manatus). Compiled By Ester Quintana-Rizzo And John Reynolds, I. I. I. CEP Technical Report No. 48. Kingston, Jamaica: UNEP Caribbean Environment Programme.

Uwagbae, M., and Van Waerebeek, K. (2010). Initial Evidence of Dolphin Takes in the Niger Delta Region and a Review of Nigerian Cetaceans. IWC SC/62/SM1.

Van Waerebeek, K., Barnett, L., Camara, A., Cham, A., Diallo, M., Djiba, A., et al. (2004). Distribution, status, and biology of the Atlantic humpback dolphin, Sousa teuszii (Kükenthal, 1892). Aq. Mamm. 30, 56-83. doi: 10.1578/AM.30.1.2004.56

Van Waerebeek, K. Bamy, I. L., Jiddou, A. M., and Campredon, P. (2008). Indeterminate Status of West African Populations of Inshore Common Bottlenose Dolphins Tursiops truncatus Cautions Against Opportunistic Live-Capture Schemes. Report to the Fondation Internationale du Banc d'Arguin, 9.

Van Waerebeek, K., Debrah, J. S., and Ofori-danson, P. K. (2014). Cetacean Landings at the Fisheries Port of Dixcove, Ghana in 2013-14: A Preliminary Appraisal. IWC SC/65/SM17.

Van Waerebeek, K., Diallo, M., Djiba, A., Ndiaye, P., and Ndiaye, E. (1997a). Cetacean Research in Senegal 1995-97: An overview. IWC SC/49/SM10.
Van Waerebeek, K., Montes, D., Onton, K., Santillan, L., Bressem, M., and Vega, D. (1997b). Las pesquerias de centolla y centollón y su interferencia con mamíferos marinos. Amb. y Des. XIII 4, 64-69.

Van Waerebeek, K., Montes, D., Onton, K., Santillan, L., Bressem, M., and Vega, D. (2002). Fisheries Related Mortality of Small Cetaceans in Neritic Waters of Peru in 1999-2001. IWC SC/54/SM10.

Van Waerebeek, K., and Ofori-Danson, P. K. (1999). A First Checklist of Cetaceans of Ghana, Gulf of Guinea, and a Shore-Based Survey of Interactions with Coastal Fisheries. IWC SC/51/SM35.

Van Waerebeek, K., Ofori-Danson, P. K., and Debrah, J. (2009). The cetaceans of Ghana, a validated faunal checklist. West Afr. J. Appl. Ecol. 15, 61-90. doi: 10.4314/wajae.v15i1.49428

Van Waerebeek, K., and Reyes, J. C. (1990). Catch of small cetaceans at Pucusana Port Central. Biol. Conserv. 51, 15-22.

Van Waerebeek, K., and Reyes, J. C. (1994a). Interactions between small cetaceans and Peruvian fisheries in 1998/1989 and analysis of trends. Rep Int. Whal. Commn, Special Issue 15, 495-502.

Van Waerebeek, K., and Reyes, J. C. (1994b). Post-Ban small cetacean takes off Peru: A review. Rep Int. Whal. Commn 15, 503-519.

Van Waerebeek, K., Van Bressem, M. F., Alfaro-shigueto, J., Sanino, G. P., Montes, D., and Ontón, K. (1999). A Preliminary Analysis of Recent Captures of Small Cetaceans in Peru and Chile. IWC SC/51/SM17.

Vidal, O., Van Waerebeek, K., and Findley, L. T. (1994). cetaceans and Gillnet Fisheries in Mexico, Central America and the Wider Caribbean: a preliminary review. Rep. Int. Whal. Commn 15, 221-236.

Weir, C., Debrah, J., Ofori-Danson, P., Pierpoint, C., and Van Waerebeek, K. (2008). Records of Fraser's dolphin Lagenodelphis hosei Fraser 1956 from the Gulf of Guinea and Angola. Afr. J. Mar. Sci. 30, 241-246. doi: 10.2989/AJMS.2008.30.2.4.554

Weir, C. R., and Pierce, G. J. (2013). A review of the human activities impacting cetaceans in the eastern tropical Atlantic. Mamm. Rev. 43, 258-274. doi: 10.1111/j.1365-2907.2012.00222.x

Wiles, D., and Makor, J. (2008). "Liberia," in Conservation Strategy for the West African Manatee, eds T. Dodman, M. D. D. Ndiaye, and K. Sarr (Nairobi, Kenya and Wetlands International Africa, Dakar: UNEP), 51-52.

Conflict of Interest Statement: The authors declare that the research was conducted in the absence of any commercial or financial relationships that could be construed as a potential conflict of interest.

The reviewer MPS and handling Editor declared their shared affiliation, and the handling Editor states that the process nevertheless met the standards of a fair and objective review.

Copyright $\odot 2016$ Cosentino and Fisher. This is an open-access article distributed under the terms of the Creative Commons Attribution License (CC BY). The use, distribution or reproduction in other forums is permitted, provided the original author(s) or licensor are credited and that the original publication in this journal is cited, in accordance with accepted academic practice. No use, distribution or reproduction is permitted which does not comply with these terms. 